\title{
RADIOCARBON DATING OF INDIVIDUAL FATTY ACIDS AS A TOOL FOR REFINING ANTARCTIC MARGIN SEDIMENT CHRONOLOGIES
}

\author{
Naohiko Ohkouchi ${ }^{1,2}$ • Timothy I Eglinton ${ }^{1,3}$ • John M Hayes ${ }^{4}$ \\ ABSTRACT. We have measured the radiocarbon contents of individual, solvent-extractable, short-chain $\left(\mathrm{C}_{14}, \mathrm{C}_{16}\right.$, and $\left.\mathrm{C}_{18}\right)$ \\ fatty acids isolated from Ross Sea surface sediments. The corresponding ${ }^{14} \mathrm{C}$ ages are equivalent to that of the post-bomb dis- \\ solved inorganic carbon (DIC) reservoir. Moreover, molecular ${ }^{14} \mathrm{C}$ variations in surficial (upper $15 \mathrm{~cm}$ ) sediments indicate \\ that these compounds may prove useful for reconstructing chronologies of Antarctic margin sediments containing uncertain \\ (and potentially variable) quantities of relict organic carbon. A preliminary molecular ${ }^{14} \mathrm{C}$ chronology suggests that the accu- \\ mulation rate of relict organic matter has not changed during the last $500{ }^{14} \mathrm{C}$ yr. The focus of this study is to determine the \\ validity of compound-specific ${ }^{14} \mathrm{C}$ analysis as a technique for reconstructing chronologies of Antarctic margin sediments.
}

\section{INTRODUCTION}

The stability of the West Antarctic Ice Sheet (WAIS) is thought to be sensitive to global warming because a major part of this ice sheet is grounded below sea level (Mercer 1978; Alley and Whillans 1991; Oppenheimer 1998). To investigate its behavior in relation to climatic change, many studies have focused on past variability of the WAIS over the past glacial-interglacial cycle. Since Antarctic margin sediments generally lack calcareous foraminifera, acid-insoluble organic carbon (AIOC) has often been used to establish radiocarbon chronologies for sediments deposited over the late Quaternary (Domack et al. 1989; Andrew et al. 1999; Licht et al. 1996; Harris et al. 1996). However, Antarctic margin sediments commonly contain variable amounts of reworked sediment eroded from the Antarctic continent (Sackett et al. 1974). This "contamination" by relict organic carbon (OC) leads to anomalously old core-top ages or to age reversals down-core, which leaves the reconstruction of oceanic environments around Antarctica far behind that of the Laurentide Ice Sheet (e.g., Bond and Lotti 1995). In an attempt to overcome this problem, we applied compound-specific ${ }^{14} \mathrm{C}$ dating (Eglinton et al. 1996, 1997) to a suite of Ross Sea sediments. Pearson et al. (2000) reported that individual sterols in laminated sediments from the Santa Monica Basin served as effective tracers of surface water dissolved inorganic carbon. A goal of this paper is to determine the ${ }^{14} \mathrm{C}$ contents of different fatty acids with a view toward identifying those suitable for reconstruction of sediment chronologies.

\section{METHODS}

In the Ross Sea, sediments were collected using a box corer from the Chinstrap $\left(76^{\circ} 19.9^{\prime} \mathrm{S}\right.$, $165^{\circ} 01.5^{\prime} \mathrm{E}$, water depth $827 \mathrm{~m}$ ), Gentoo $\left(76^{\circ} 20.4^{\prime} \mathrm{S}, 172^{\circ} 56.2^{\prime} \mathrm{E}, 623 \mathrm{~m}\right)$, Emperor $\left(76^{\circ} 58.9^{\prime} \mathrm{S}\right.$, $\left.171^{\circ} 59.7^{\prime} \mathrm{E}, 670 \mathrm{~m}\right)$, and Fairy $\left(77^{\circ} 58.3^{\prime} \mathrm{S}, 178^{\circ} 03.0^{\prime} \mathrm{W}, 671 \mathrm{~m}\right)$ sites during the ROAVERRS (Research on Ocean-Atmosphere Variability and Ecosystem Response in the Ross Sea program) cruise on the R/V Nathaniel B Palmer in December 1998. The Chinstrap site represents a region where diatoms bloom during the austral summer, whereas the Emperor and Gentoo sites are located in a region of extensive blooms of haptophyte algae. The Fairy site is a location where large algal blooms have not been observed. Therefore, the sediments analyzed in this study span a range of surface ocean conditions in the Ross Sea. These sediments were stored in a freezer $\left(-20^{\circ} \mathrm{C}\right)$ until analysis.

\footnotetext{
${ }^{1}$ Department of Marine Chemistry and Geochemistry, Woods Hole Oceanographic Institution, Woods Hole, Massachusetts 02543, USA.

${ }^{2}$ Corresponding author. Email: nohkouchi@jamstec.go.jp.

${ }^{3}$ Email: teglinton@whoi.edu.

${ }^{4}$ Department of Marine Geology and Physics, Woods Hole Oceanographic Institution, Woods Hole, Massachusetts 02543, USA. Email: jhayes@whoi.edu.
} 
Figure 1 Map showing study area and sample locations. The depth contour was derived from The Generic Mapping Tools (GMT; www.gmt.soest.hawaii.edu) and corresponds to 50 -m intervals.

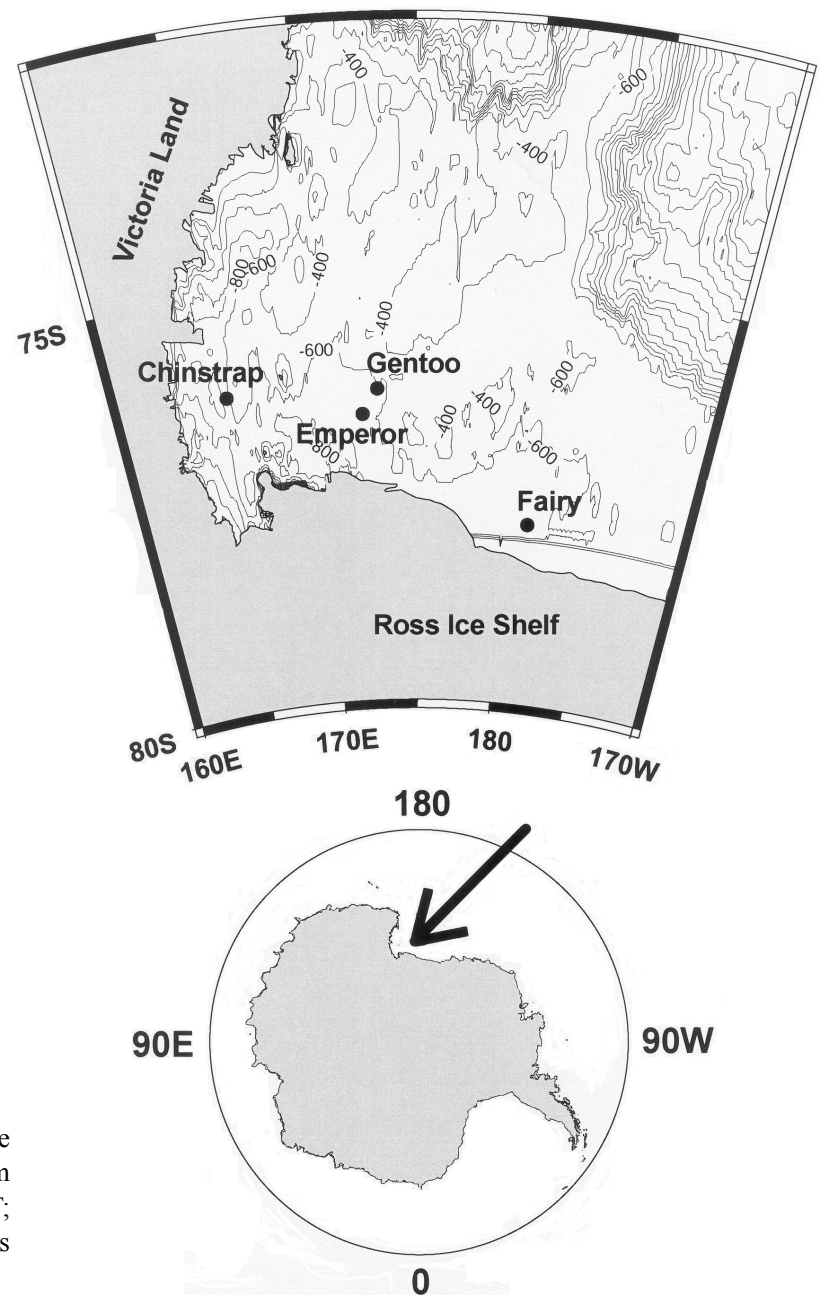

Dried sediments $(100-350 \mathrm{~g})$ were Soxhlet-extracted for 4 days with dichloromethane/ $\mathrm{MeOH}(93$ : $7, \mathrm{v} / \mathrm{v})$. The extracts were saponified by $0.7 \mathrm{M} \mathrm{KOH} / \mathrm{MeOH}$ and esterified by $\mathrm{HCl} / \mathrm{MeOH}$ under a $\mathrm{N}_{2}$ atmosphere. They were separated into fractions by pressurized flash chromatography. Compounds were quantified using a HP5890 gas chromatograph (GC) equipped with CPSil-5CB column (60 m $\times 0.25 \mathrm{~mm}$ i.d., film thickness $0.25 \mu \mathrm{m}$ ) and FID. Individual compounds were isolated and purified using methods described elsewhere (Eglinton et al. 1996). Briefly, samples containing fatty acid methyl esters (FAMEs) were repeatedly injected to a preparative-capillary GC equipped with Gerstel CIS injector and CPSil 5CB column $(100 \mathrm{~m} \times 0.52 \mathrm{~mm}$ i.d., film thickness $0.25 \mu \mathrm{m})$ and individual FAMEs were trapped from the column effluent. Microcolumn $\mathrm{SiO}_{2}$ chromatography (hexane/ dichloromethane, $2: 1, \mathrm{v} / \mathrm{v}$ ) was used to remove column bleed and the individual compounds were transferred to quartz tubes for combustion. The resulting $\mathrm{CO}_{2}$ was converted to graphite (Pearson et al. 1998). The purity of each compound was determined based on the GC-FID analysis of an aliquot of the isolated component. ${ }^{14} \mathrm{C}$ content in the samples was determined at the National Ocean Science Accelerator Mass Spectrometry (NOSAMS) Facility at the Woods Hole Oceanographic Institution. All ${ }^{14} \mathrm{C}$ values are corrected for the contribution of methyl carbon obtained from $\mathrm{MeOH}\left({ }^{14} \mathrm{C}_{\mathrm{MeOH}}=\right.$ $-955.6 \%$ ) during the esterification by isotope mass balance. 


\section{RESULTS AND DISCUSSION}

Concentrations of solvent-extractable fatty acids (FAs) in the Ross Sea surface sediments show a bimodal pattern with peaks at $\mathrm{C}_{16}$ and $\mathrm{C}_{24}$ or $\mathrm{C}_{26}$ and have a strong predominance of even carbonnumber chains (Figure 2). Although sediments from the Chinstrap site are enriched in FAs relative to other sites, relative abundances of FAs to the total organic carbon (TOC) content are rather similar between sites. Concentrations of short-chain $\left(\mathrm{C}_{14}, \mathrm{C}_{16}\right.$, and $\left.\mathrm{C}_{18}\right)$ FAs decrease with depth in the Chinstrap site. The total concentrations of short-chain FAs in shallower samples $(0-2$ and 3-6 cm) are 8.80 and $8.78 \mu \mathrm{g} / \mathrm{g}$ dry sediment (ds), respectively, whereas in deeper samples $(6-9,9-12$, and $12-15 \mathrm{~cm})$ they are lower than $3.5 \mu \mathrm{g} / \mathrm{g}$ ds. In contrast, total concentrations of long-chain $\left(\mathrm{C}_{24}, \mathrm{C}_{26}\right.$, and $\mathrm{C}_{28}$ ) FAs for all samples fall in a narrow range from 2.0 to $3.2 \mu \mathrm{g} / \mathrm{g}$ ds. Since TOC contents of these sediments vary little with depth, the reduction of the short-chain FAs may reflect their lability compared with the TOC.

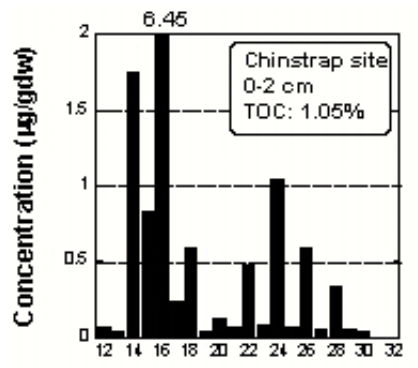

Carbon number

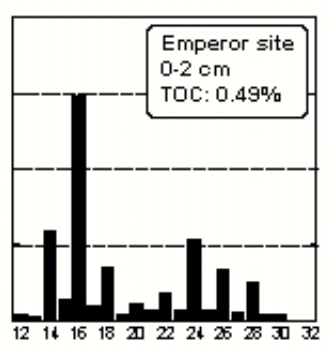

Carbon number

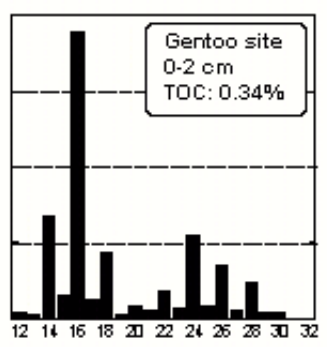

Carbon number

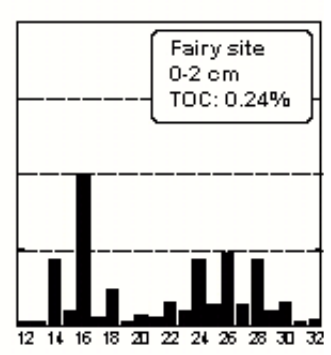

Carbon number

Figure 2 Concentrations of solvent-extractable $\mathrm{C}_{12}-\mathrm{C}_{32}$ fatty acids relative to sediment dry weight in surface sediments from the Chinstrap, Gentoo, Emperor, and Fairy sites. Total organic carbon contents of these sediments are also shown.

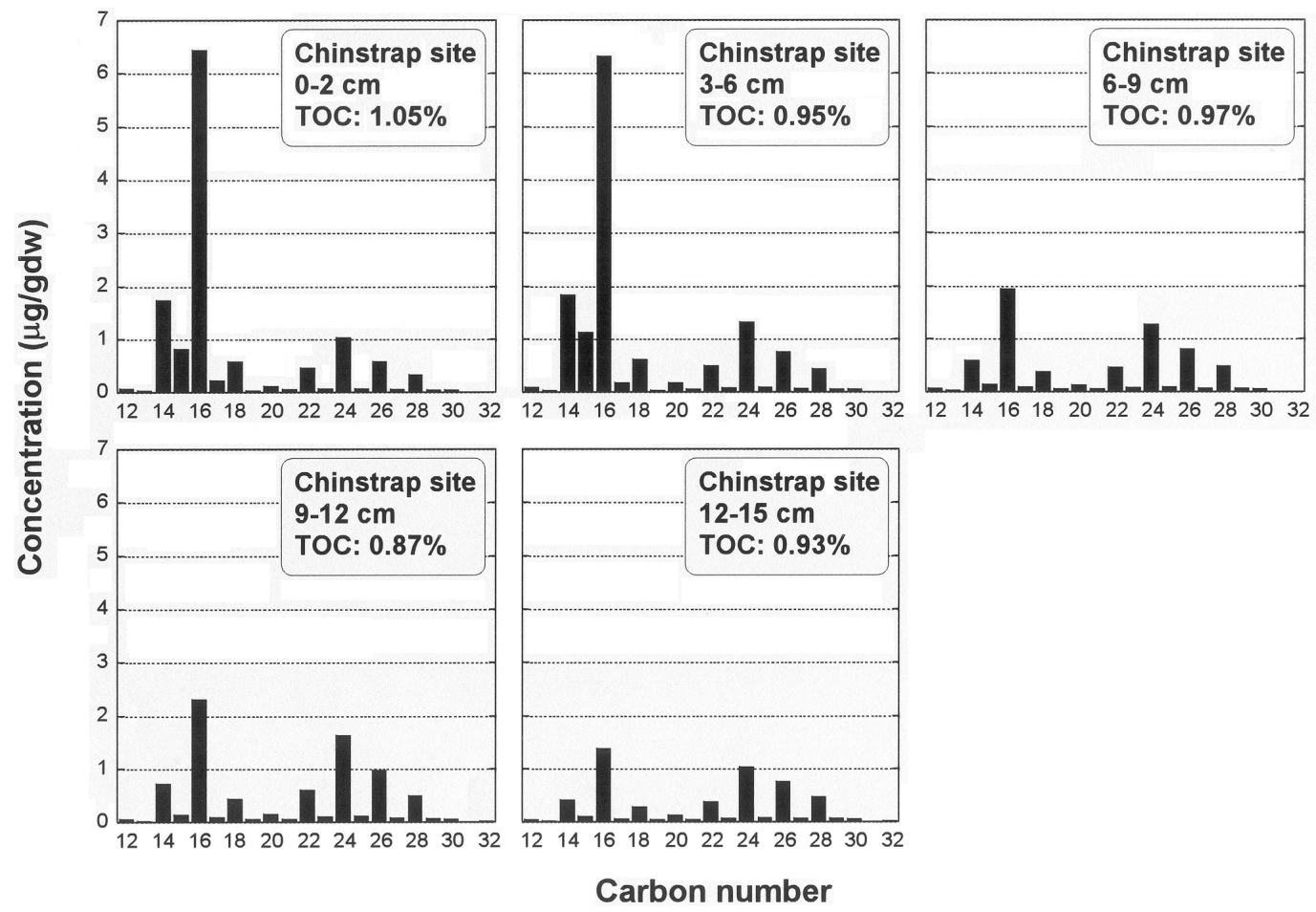

Figure 3 Concentrations of solvent-extractable $\mathrm{C}_{12}-\mathrm{C}_{32}$ fatty acids relative to sediment dry weight in down-core sediments from the Chinstrap site. Total organic carbon contents of these sediments are also shown. 
As shown in Figure 4, the short-chain FAs are significantly enriched in ${ }^{14} \mathrm{C}$ relative to the AIOC. With the exception of the Fairy site, the $\Delta^{14} \mathrm{C}$ values of the short-chain FAs are relatively uniform and mostly fall in the range of the post-bomb dissolved inorganic carbon (DIC) reservoir $(-100 \pm 20 \%$ ) in this region (Berkman and Forman 1996; Gordon and Harkness 1992). Since these short-chain FAs are produced by not only marine algae but also by other organisms (including animals and bacteria) as membrane components, energy storage material, heat insulating material, etc. (Harwood 1996), some fraction of these FAs could have been produced by these heterotrophic organisms. Whatever their immediate sources are, our results indicate that the carbon in the short-chain FAs is derived ultimately from the photosynthetic fixation of surface ocean DIC within the last $40 \mathrm{yr}$, during which levels of atmospheric ${ }^{14} \mathrm{C}$ have been elevated by the testing of weapons. An important implication is that contributions of $\mathrm{C}_{14}, \mathrm{C}_{16}$, and $\mathrm{C}_{18} \mathrm{FAs}$ from relict, ${ }^{14} \mathrm{C}$-free OC eroded from the Antarctic continental erosion are not significant at these sites. If this dominance of autochthonous sources prevails downcore, ${ }^{14} \mathrm{C}$ analyses of solvent-extractable, short-chain FAs can provide a basis for accurate sediment chronologies. At the Fairy site, ${ }^{14} \mathrm{C}$ values of the short-chain FAs are $70-150 \%$ lower than that of the post-bomb DIC. Although we do not have confirming evidence, deep bioturbation and/or a low sedimentation rate may cause the reduced ${ }^{14} \mathrm{C}$ level in the FAs.

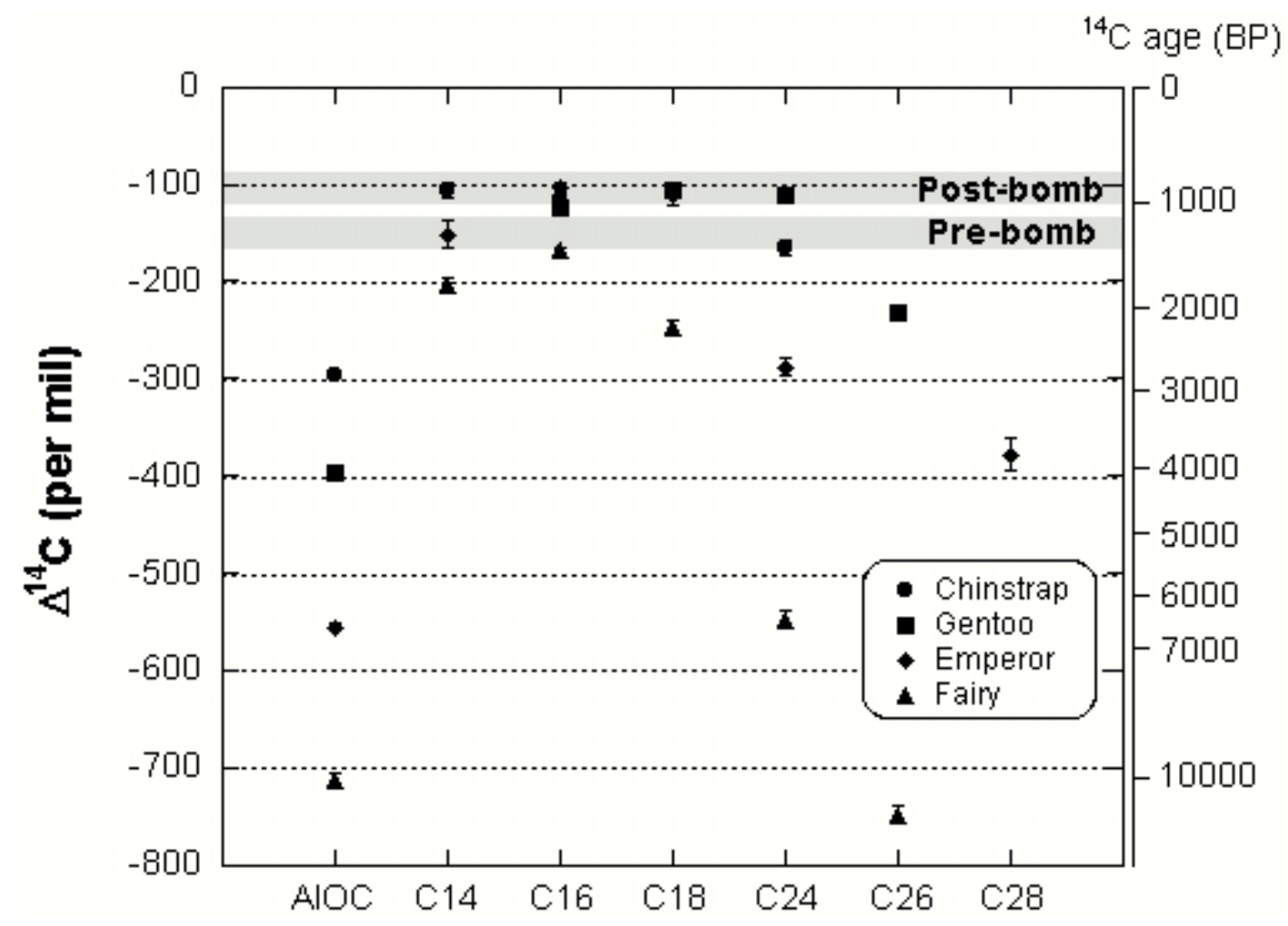

Figure 4 Radiocarbon activities (as ${ }^{14} \mathrm{C}$ ) of individual fatty acids (circles) and acid-insoluble organic carbon (AIOC; squares) in the surface ( $0-2 \mathrm{~cm}$ ) sediments collected from the Chinstrap, Emperor, Gentoo, and Fairy sites in the Ross Sea. Numbers in the diagram indicate carbon numbers of fatty acids. The error bars represent \pm 1 standard deviation. Shaded areas indicate ${ }^{14} \mathrm{C}$ activities of DIC reservoir in the Ross Sea during the post-bomb (after 1957) and pre-bomb (before 1957) eras (Berkman and Forman 1996; Gordon and Harkness 1992). 
In marked contrast to the short-chain FAs, the long-chain FAs are substantially more depleted in ${ }^{14} \mathrm{C}$ but generally enriched relative to the AIOC. In general, the shorter the chain length, the younger the age. Even carbon-numbered chains are strongly predominant among the long-chain FAs at these sites, suggesting derivation from unaltered biological debris. The distribution is not unlike that in waxes from the leaves of higher plants (Eglinton and Hamilton 1967) but eolian transport would then be indicated and a uniform distribution among sites would be expected (Ohkouchi et al. 2000). A relationship to the long-chain FAs found in soils in Antarctic dry valleys (Matsumoto et al. 1981), which could also be delivered by wind erosion, is unlikely for heterogeneous FA patterns because the even- C/odd-C concentration ratios in those soil FAs are much lower than observed in the sediments. The observed variations in $\Delta^{14} \mathrm{C}$ (Figure 4) indicate (i) the presence of at least some recentlyproduced, long-chain FAs, presumably of algal or zooplanktonic origin (Volkman et al. 1998), and (ii) significant variations in the modern/relict mixing ratio for these compounds.

To check the usefulness of the ${ }^{14} \mathrm{C}$ content of the short-chain FAs as chronological tools at greater depths of the sediments, a vertical profile of ${ }^{14} \mathrm{C}$ content of $\mathrm{C}_{16}$ FA was examined for 5 depth intervals from the upper $15 \mathrm{~cm}$ of a box core from the Chinstrap site (Figure 5). Essentially constant ${ }^{14} \mathrm{C}$

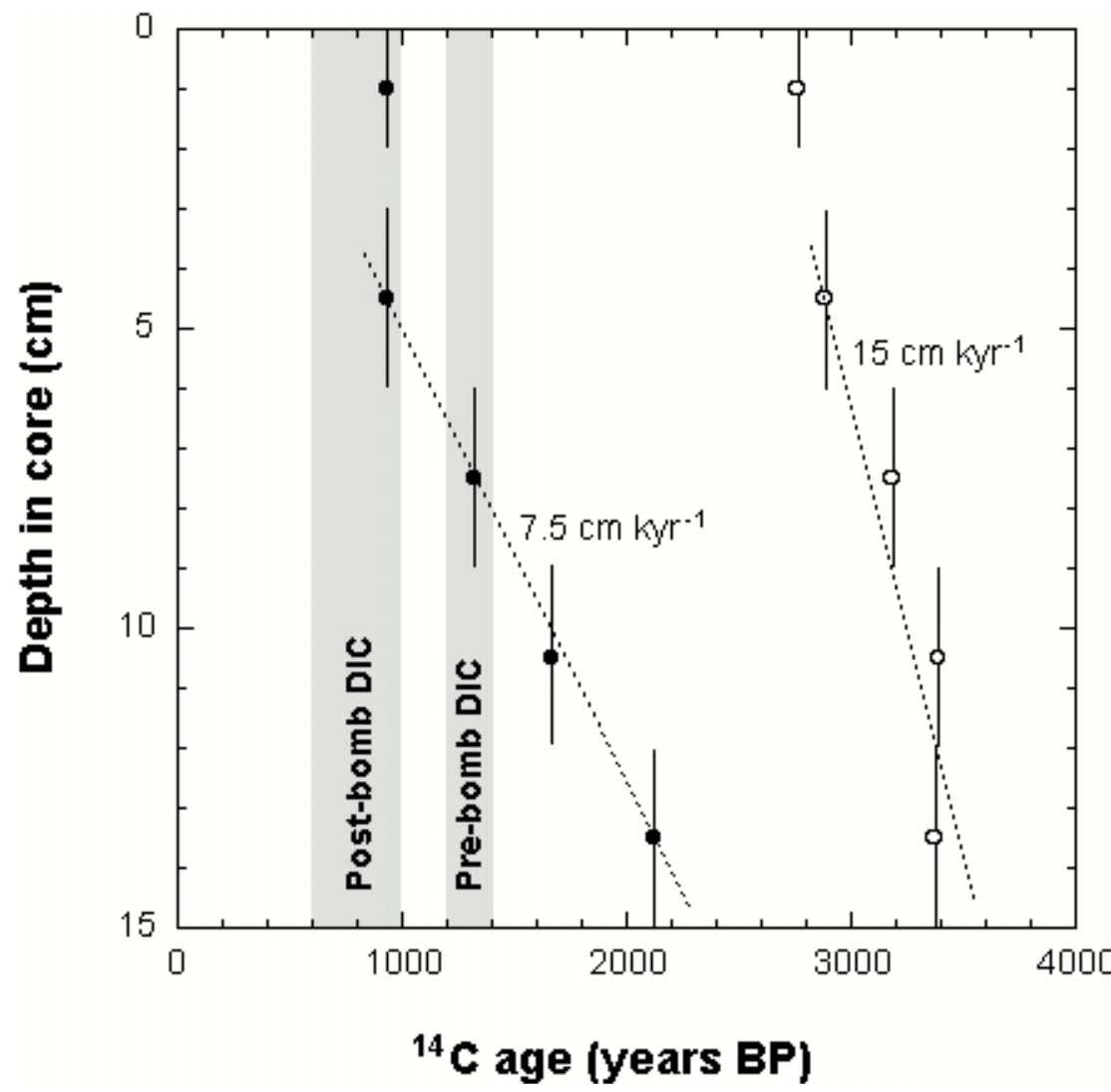

Figure 5 Depth-related variations in ${ }^{14} \mathrm{C}$ ages of the $\mathrm{C}_{16}$ fatty acid (circles) and acid-insoluble organic carbon (AIOC; squares) in the down-core sediments from the Chinstrap site. In the depth range 6-9 $\mathrm{cm}$, a mixture of $\mathrm{C}_{14}$ and $\mathrm{C}_{16}$ fatty acids was measured. The error bars of the ${ }^{14} \mathrm{C}$ age represent a \pm 1 standard deviation. Shaded areas indicate the post-bomb and pre-bomb DIC reservoir ages (Berkman and Forman 1996; Gordon and Harkness 1992). 
ages are evident for the samples from the upper $6 \mathrm{~cm}$, corresponding to the depth of the bioturbated mixed layer. The ages of these 2 samples are nearly identical to the post-bomb DIC reservoir age. The age of the $\mathrm{C}_{16} \mathrm{FA}$ in the mixed layer mainly reflects the balance between the bioturbation rate and degradation rate of this compound. Using a model analogous to the $\mathrm{CaCO}_{3}$ dissolution and mixing (Broecker et al. 1991), the ${ }^{14} \mathrm{C}$ age of the FA will correspond with the post-bomb DIC reservoir age if the FA reaching the sea floor is rapidly (within a few yr) mixed and if its half-life in the mixed layer is less than $30 \mathrm{yr}$. The latter is a reasonable assumption based on studies of FA degradation in marine sediments (Canuel and Martens 1996). In Antarctic margin sediments, such as those underlying the Ross Sea, elevated bioturbation rates may be caused by the high activity of benthos, supported by the extremely high flux of organic detritus (DiTullio et al. 2000). The ${ }^{14} \mathrm{C}$ ages of AIOC roughly parallel that of the $\mathrm{C}_{16} \mathrm{FA}$ with an offset of $1200-2000{ }^{14} \mathrm{C}$ yr. Sedimentation rates estimated from $\mathrm{C}_{16} \mathrm{FA}$ and AIOC chronologies are around 7.5 and $15 \mathrm{~cm} \mathrm{kyr}^{-1}$, respectively. The two-fold difference between FA- and AIOC-based rates of sedimentation could be explained if the fraction of relict AIOC increases with depth. Alternatively, it could indicate that with increasing depth progressively greater portions of the $\mathrm{C}_{16} \mathrm{FA}$ were derived from relict carbon, presumably by bacterial attack on imported kerogen (Petsch et al. 2001).

Assuming AIOC the in Ross Sea sediments is mainly derived from 2 sources, marine autochthonous and relict, we can estimate the relative contribution of relict $\mathrm{OC}$ from the isotopic difference between the short-chain FAs and AIOC. Terrestrial OC transported from continents other than Antarctica through the atmosphere should be a minor component. Assigning the $\Delta^{14} \mathrm{C}$ value of autochthonous organic matter as that of the $\mathrm{C}_{16} \mathrm{FA}$ and $\Delta^{14} \mathrm{C}$ of relict organic matter of infinite ${ }^{14} \mathrm{C}$ age $\left(\Delta^{14} \mathrm{C}=-1000 \%\right.$ ), we calculated the minimum contribution of relict OC to the AIOC (Figure 6). At the Emperor and Fairy sites, the contributions of relict OC are higher than $50 \%$. At the Chinstrap site, the contribution of relict OC is relatively invariant, comprising about $20 \%$ of the total AIOC. The relative abundance of relict $\mathrm{OC}$ could be a function of variable input of debris-laden glacial ice in the overlying water column. Our record suggests that the input of relict sediments to the Ross Sea (potentially related to the melting rate of glacial ice) did not change substantially during the last 600 ${ }^{14} \mathrm{C}$ yr.

Figure 6 Estimated minimum fraction of relict organic carbon (shaded area) in the acid-insoluble organic carbon (AIOC) in the surface sediments from the Emperor, Gentoo, Fairy, and Chinstrap sites, based on the two-source model explained in the text.

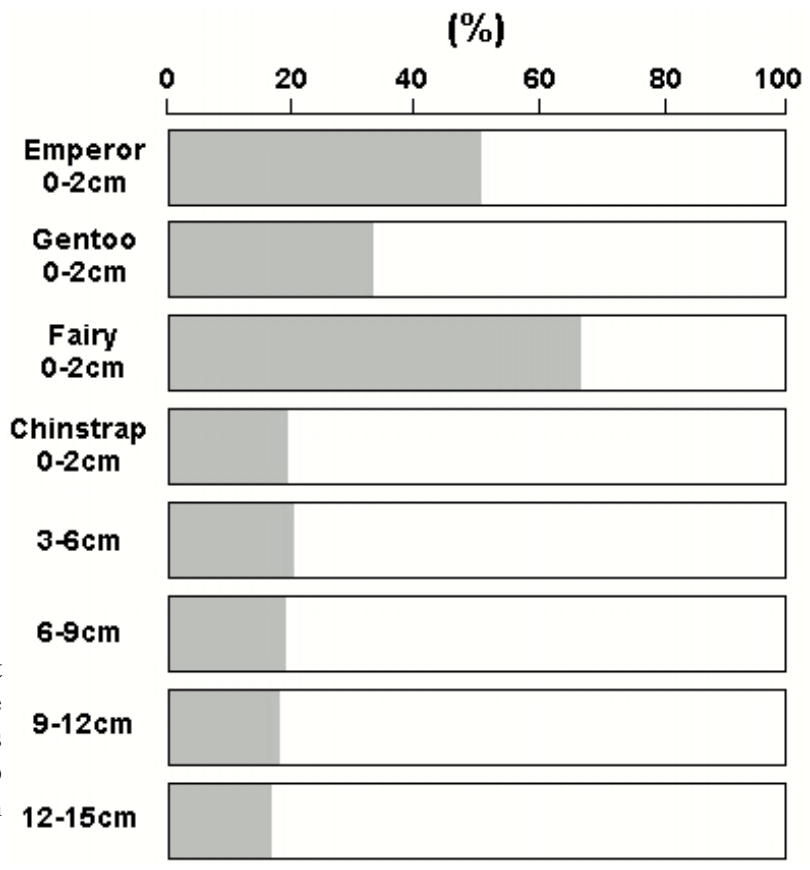


Overall, this initial application of compound-specific ${ }^{14} \mathrm{C}$ dating to Antarctic margin sediments clearly shows a potential utility of this approach for developing sediment chronologies. In addition to FAs, sterols and isoprenoid alkenes, which are also derived from phytoplankton (Nichols et al. 1988), have been identified in Antarctic margin sediments and could prove as useful for ${ }^{14} \mathrm{C}$ dating (Pearson et al. 2000). The short-chain FAs are particularly useful because they are among the most abundant lipid-class compounds in the Antarctic margin sediments (e.g., Venkatesan and Kaplan 1987). Since prior studies of sediment cores have yielded core-top ${ }^{14} \mathrm{C}$ ages of AIOC of $2000-4000$ yr BP (Licht et al. 1998), the timing of WAIS recession and/or advance estimated from these dates may be overestimated by $1000-3000{ }^{14} \mathrm{C}$ yr. Substantially improved chronologies can be obtained if the age scale is corrected for the core-top age but this approach may be prone to error because it assumes a constant age offset downcore. Without the application of appropriate corrections for relict $\mathrm{OC}$, molecular ${ }^{14} \mathrm{C}$ measurements provide an effective way of eliminating such interferences.

\section{ACKNOWLEDGMENTS}

We thank J Grebmeier and J P Barry for providing samples, and J Andrews and K Licht for encouraging us to undertake this study. We also thank A P McNichol and the NOSAMS staff for ${ }^{14} \mathrm{C}$ measurements, A Pearson for technical advice, and D Montlucon for assistance in the laboratory. This research was supported by the grants from NSF (OCE-9907129, OCE-9809624, and OPP9909782), and Japan Society for the Promotion of Science.

\section{REFERENCES}

Alley RB, Whillans IM. 1991. Changes in the West Antarctic Ice Sheet. Science 254:959-63.

Andrews JT. 1999. Problems and possible solutions concerning radiocarbon dating of surface marine sediments, Ross Sea, Antarctica. Quaternary Research 52: 206-16.

Berkman PA, Forman SL. 1996. Pre-bomb radiocarbon and the reservoir correction for calcareous marine species in the Southern Ocean. Geophysical Research Letters 23:363-66.

Bond G, Lotti R. 1995. Iceberg discharges into the North Atlantic on millennial timescales during the last deglaciation. Science 267:1005-266.

Broecker WS, Klas M, Clark E, Bonani G, Ivy S, Wolfli W. 1991. The influence of $\mathrm{CaCO}_{3}$ dissolution on coretop radiocarbon ages for deep-sea sediments. Paleoceanography 6:593-608.

Canuel EA, Martens CS. 1996. Reactivity of recently deposited organic matter: degradation of lipid compounds near the sediment-water interface. Geochimica et Cosmochimica Acta 60:1793-806.

DeMaster DJ, Ragueneau O, Nittouer CA. 1996. Preservation efficiencies and accumulation rates for biogenic silica and organic C, N, and P in high-latitude sediments: the Ross Sea. Journal of Geophysical Research 101:18501-18.

DiTullio GR, Grebmeier JM, Arrigo KR, Lizotte MP, Robinson DH, Leventer A, Barry JP, van Woert ML, Dunbar RB. 2000. Rapid and early export of Phaeocystis Antarctica blooms in the Ross Sea, Antarctica. Nature 404:595-8.
Domack EW, Jull AJT, Anderson JB, Linick TW, Williams CR. 1989. Application of tandem accelerator mass-spectrometer dating to late Pleistocene-Holocene sediments of the east Antarctic continental shelf. Quaternary Research 31:277-87.

Eglinton G, Hamilton RJ. 1967. Leaf epicuticular waxes. Science 156:1322-35.

Eglinton TI, Aluwihare LI, Bauer JE, Druffel ERM, McNichol AP. 1996. Gas chromatographic isolation of individual compounds from complex matrices for radiocarbon dating. Analytical Chemistry 68:904-12.

Eglinton TI, Benitez-Nelson BC, Pearson A, McNichol AP, Bauer JE, Druffel ERM. 1997. Variability in radiocarbon ages of individual organic compounds from marine sediments. Science 277:796-9.

Gordon JE, Harkness DD. 1992. Magnitude and geographic variation of the radiocarbon content in Antarctic marine life: implications for reservoir corrections in radiocarbon dating. Quaternary Science Reviews 11:697-708.

Harris PT, O’Brien PE, Sedwick P, Truswell EM. 1996. Late Quaternary history of sedimentation on the Mac. Robertson Shelf, east Antarctica: problems with ${ }^{14} \mathrm{C}$ dating of marine sediment cores. Papers and Proceedings of the Royal Society of Tasmania 130:47-53.

Harwood JL. 1996. Recent advances in the biosynthesis of plant fatty acids. Biochemica et Biophysica Acta 1301:7-56.

Licht KL, Jennings AE, Andrews JT, Williams KM. 1996. Chronology of late Wisconsin ice retreat from the western Ross Sea, Antarctica. Geology 24:223-6. 
Licht KJ, Cunningham WL, Andrews JT, Domack EW, Jennings AE. 1998. Establishing chronologies from acid-insoluble organic ${ }^{14} \mathrm{C}$ dates on Antarctic (Ross Sea) and Arctic (North Atlantic) marine sediments. Polar Research 17:203-16.

Matsumoto G, Torii T, Hanya T. 1981. High abundances of long-chain normal alkanoic acids in Antarctic soil. Nature 290:688-90.

Mercer JH. 1978. West Antarctic ice sheet and $\mathrm{CO}_{2}$ greenhouse effect: a threat of disaster. Nature 271: 321-5.

Nichols PD, Volkman JK, Palmisano AC, Smith GA, White DC. 1988. Occurrence of an isoprenoid $\mathrm{C}_{25}$ diunsaturated alkene and high neutral lipid content in Antarctic sea-ice diatom communities. Journal of Phycology 24:90-6.

Ohkouchi N, Kawamura K, Takemoto N, Ikehara M, Nakatsuka T. 2000. Implications of carbon isotope ratios of $\mathrm{C}_{27}-\mathrm{C}_{33}$ alkanes and $\mathrm{C}_{37}$ alkenes for the sources of organic matter in the Southern Ocean surface sediments. Geophysical Research Letters 27:233-6.

Oppenheimer M. 1998. Global warming and the stability of the West Antarctic Ice Sheet. Nature 393:325-32.

Pearson A, Eglinton TI, McNichol AP. 2000. An organic tracer for surface ocean radiocarbon. Paleoceanography 15:541-50.

Petsch ST, Eglinton TI, Edwards KJ. 2001. ${ }^{14} \mathrm{C}$ dead living biomass: evidence for microbial assimilation of ancient organic carbon during shale weathering. Science 292:1127-31.

Pearson A, McNichol AP, Schneider RJ, von Reden KF. 1998. Microscale AMS ${ }^{14} \mathrm{C}$ measurement at NOSAMS. Radiocarbon 40:61-75.

Pearson A, Eglinton TI, McNichol AP. 2000. An organic tracer for surface ocean radiocarbon. Paleoceanography 15:541-50.

Sackett WM, Poag CW, Eadie BJ. 1974. Kerogen recycling in the Ross Sea, Antarctica. Science 185:1045-7.

Stuiver M, Polach HA. 1977. Discussion: reporting of ${ }^{14} \mathrm{C}$ data. Radiocarbon 28:355-63.

Venkatesan MI, Kaplan IR. 1987. The lipid geochemistry of Antarctic marine sediments: Bransfield Strait. Marine Chemistry 21:347-75.

Volkman JK, Barrett SM, Blackburn SI, Mansour MP, Sikes EL, Gelin F. 1998. Microalgal biomarkers: a review of recent research developments. Organic Geochemistry 29:1163-79. 